\title{
Evaluation of selected financial aspects in the Czech Republic: a research study about the international activities of Czech business
}

\author{
Lucie Meixnerová ${ }^{1, *}$ \\ ${ }^{1}$ The Institute of Technology and Business in České Budějovice, Okružní 517/10, 370 01, \\ České Budějovice
}

\begin{abstract}
The paper deals with the evaluation of selected financial aspects of micro, small and medium-sized enterprises in the Czech conditions in the context of the international activities. The aim of this paper is to identify and evaluate whether there are dependencies between these indicators in the context of domestic and international environment by using selected methods. In the article are evaluated the results of our own survey of the development of micro, small and medium enterprises in the years 20092016, with a total of 650 respondents (SMEs). The author calculates and describes traditional financial indicators and international activities represented by ROA, ROE and ROC. Research findings confirm that the companies operating in the Czech environment show higher growth at those micro-enterprises without international activities. Companies operating in an international environment shown stronger growth among medium-sized businesses. This is due to the benefits of international cooperation, the size and development of the company, and the growing influence of the international environment on business entities.
\end{abstract}

Key words: evaluation, business activities, financial aspects

\section{Introduction}

In a constantly changing economic environment, the irreplaceable role of small and mediumsized enterprises (SMEs) and their importance in the entire national economy is discuss more frequently. In this environment, the entrepreneurial subjects - the SMEs - also undergo changes in the management system which are part of this environment and compose of factors and forces that have a significant influence on the company and the company relations with its target market in terms of regional and international activities. The existence of competitive environment enables and international activities good functioning to only such companies which have mastered not only the entrepreneurial skills of business activity but also financial skills which play an important part. No company can thus be managed without an analysis of its financial situation, meaning the evaluation of financial soundness of the company which detects various things about both the inner and outer state of the company [1].

\footnotetext{
* Corresponding author: luciemeixnerova@seznam.cz
} 
The objective of the paper is to analyze the selected financial aspects of the micro, small and medium-sized enterprises of the Czech Republic in the international context by using selected mathematical-statistical methods. These dependencies are assessed in relation to the international activities from the profit or loss statement, assets, and capital structure of the analyzed subjects for the period 2009-2016. For the specific enumerations of dependencies among the examined factors, the correlation and regression analysis was used. The paper follows the research implemented in the field of small and medium-sized enterprises [1]. Currently, there is no similar research about Czech business with international activities in the Czech Republic. This paper as well as the implemented research and other similar international papers have become integral parts of the information and confirmation of business entities development in the Czech Republic. The paper follows the research [1] and the authors' own research. The information provided is valuable for the future and prospects of businesses and regions and can be used not only for own business needs but also for the public and other organizations (investors, business groups, state institutions or foreign institutions, etc.) which are closely connected with international activities, either economically or financially.

\subsection{Literature Review}

The role of SMEs is quite well researched and documented, as can be easily demonstrated by several studies [2], [3], [4], [5]. All these papers state the importance of SMEs in GDP or GNP and employment. These studies also research the above mentioned issues on the national level, the level of the whole country. There are studies which brings in the topic of international and are connecting SMEs and their international links, such as the ownership [6] which is focused on debt costs or [7] which is focused on behaviour and performance or [8] which is focused on performance. Empirical study has confirmed that the Czech Republic, Hungary and Slovakia has poorer results added values than Sweden, Belgium, Denmark and Finland [9]. Growth of efficiency of economic processes, added value and overall business success in small and medium enterprises depends on selection of the right sphere of business, application of research and development, adequate investments and cooperation between individual sectors or on the level of investment activity The study from authors $\mathrm{Hu}$, Chang, Hsu [10] deals with the relationship between the capital structure and the business performance. It was found out that the capital structure has not sustained effective funding required for the growth and development of the business. The use of equity and foreign capital for funding also affects the tax base. The issue of the capital structure of a business in the context of the taxation by the corporate and personal income tax was analyzed by DeAngelo and Masulis [11] when the expense of foreign capital - interest - is a tax shield. Brennan and Schwartz [12] state that for funding the assets a combination of equity and foreign sources is always used, because the optimal capital structure will almost entirely consist of debt. The analysis of the factors affecting the involvement of the foreign capital in a business is further described by Lee and Hyun [13]. The choice of the capital structure affects not only the degree of debt but also the amount of profit or the operating leverage indicator. In search for optimal sources for funding the assets, it is appropriate to respect the golden balance rule of funding, i.e. the fixed assets are financed by long-term resources equity and fixed foreign capital - and the current assets are financed by short-term sources. Dittmar [14] monitored the structure of funding in the selected businesses found out that the representation ratio of equity and foreign sources depends on the business field and the nature of activities of the analyzed entity. High-growth firms choose lower leverage ratios. Firms seem to use debt financing too conservatively, and the leverage of stable, profitable firms appears particularly low [15]. 
In the Czech Republic, the factors affecting the capital structure were analysed [16]. Strýčková [16] states that the decisive factors are the cost of capital and the indebtedness of the business. To fund its assets, each business should choose such a resource structure so that the average total costs of capital were the lowest. The cost of capital includes two components, the cost of debt and the cost of equity, learn more about the average total costs in Aliyev-Ada [17]. The influence of the interest rate on funding was examined [18] conclusions confirmed that larger firms tend to have higher debt ratios than smaller firms. Rodríguez-Masero [19] confirmed the fact that the phase of the economic cycle also affects the capital structure.

\subsubsection{Accounting as a primary source of data for the financial analysis}

It is appropriate to examine the company performance evaluation also from the perspective of the financial reporting and it provides information on the financial position and performance, which is important for economic decisions of a wide range of users [20]. Accounting provides the pivotal information on the economic phenomena of the business, sources of funding and the structure of assets as well as the cost and revenue structure especially through the financial statement accounts. In the Czech Republic conditions, this issue is enacted by the provisions of the Act No. 563/1991 Coll. on Accounting, the Decree No. 500/2002 Coll. implementing particular provisions of the Act on Accounting, and Czech accounting standards. Financial statements, the items of which are exhaustively defined by the Act on Accounting, consist of the balance sheet, profit and loss account, and annex.

It is appropriate too to compare the results of the financial performance evaluation not only in the context of its development in time, but also for example according to CZ-NACE categorization codes, as the field of activity has an impact on financial and economic performance of firms [21]. It is appropriate to examine the company performance evaluation also from the perspective of the categorization of business entities. From the perspective of business economics, we divide companies to small, medium and large companies. The term 'company' is absent from accounting, this term is replaced by the term 'accounting unit'. The categorization of an accounting unit is based on the European Union directive and its categorization (micro, small, medium and large accounting unit) is dependent on the implementation of the directive in the particular country. In accordance with the rules of the European Union (Recommendation 2003/361/EC), an enterprise is considered medium-sized if the number of employees does not exceed 250, the annual turnover EUR50 million and the annual balance sheet total EUR43 million, the classification limits for a small and micro enterprise are lower.

\section{Data and methodology}

The paper follows the research implemented in the field of micro, small and medium-sized enterprises [1] and the author' own research. The primary objective of the research study was the analysis of performance of small and medium-sized enterprises in terms of international activities. Author observed a total of 650 respondents - business untities (accounting units) during the years of 2009-2016 from. The research was conducted using data from March 2013 till July 2017 and the research still continues. The basic preconditions to include a business in the research were the categorization of accounting units in the Czech Republic and company financial reports. The categorization of business entities (hereinafter referred to as the size of business) was determined by the indicators according to the Czech legislation valid from 1st January 2016. Data was collected data mostly from financial reporting (balance sheet, profit and loss statement, notes in annual reports) and also from their web pages and other official lists and databases (such us Business Register, Czech Statistical Office register 
etc.). The individual respondents were continuously investigated in terms of the changes which occurred in the examined period and were related to the development of their business activities, in direct continuity with a focus on accounting and overall business activity of the monitored businesses. The research results have been continuously processed and the data of 600 business entities out of the original 650 business entities before the statistical adjustment were used. The qualitative data obtained by the primary research were evaluated using the Microsoft Office Excel application and the statistical software IBM SPSS 19. In addition to standard scientific methods such as description, analysis, synthesis and comparison, authors also used selected methods of the regression and correlation analysis and ANOVA method. The dependency ratio between the selected characters $\mathrm{x}$ and $\mathrm{y}$ is evaluated by the correlation coefficient, the form of which is determined by (1),

$$
r=\frac{\sum_{i=1}^{n}\left(x_{i}-\bar{x}\right)\left(y_{i}-\bar{y}\right)}{\sqrt{\sum_{i=1}^{n}\left(x_{i}-\bar{x}\right)^{2} \sum_{i=1}^{n}\left(y_{i}-\bar{y}\right)^{2}}},
$$

For expressing the progress of the dependent variable $\mathrm{y}$ on the independent variable $\mathrm{x}$, the regression analysis is used. The form of the regression function is determined by (2),

$$
y=B_{0}+B_{1} x+\varepsilon,
$$

where $\varepsilon$ is a random error, $B_{0}$ and $B_{1}$ are the population model coefficients.

The determination index R2 (3) expresses to what extent the ascertained regression function depicts the dependence of Y on X,

$$
R^{2}=\frac{S_{T}}{s_{y}}
$$

where ST is the theoretical sum of squares and SY is the total sum of squares. The variance of Anova, which is dealt with in more detail in [22] [23] and the aim is to find out if one statistical character affects the second character, whether the factor affects the values of the second statistical set. According to the study from Hinke [24] no used a probabilistic neural network, a generalised regression neural network, a radial basis function network, a three-layer perceptron network and a four-layer perceptron network for planning financial statements because the method is limited, only for a stable company, not for studies more enterprises.

The individual conclusions listed in own surveys and in correlation and in regression and their subsequent evaluation are influenced by the respondents and, therefore, with regard to the given objective, Indicators were chosen related to the enterprises performance in international activities:

- the micro accounting unit, in the paper marked "micro",

- the small accounting unit, in the paper marked "small",

- the medium accounting unit, in the paper marked "medium",

- return on assets, in the paper marked "ROA",

- return on equity, in the paper marked "ROE",

- return on sales, in the paper marked "ROS",

- the international business are activities on foreign market. 
On the basis of present knowledge, experience and above-mentioned information, the following hypotheses were formulated:

$\mathrm{H} 0$ : International activities have no effect on company performance at micro enterprise (a), small enterprise (b), and medium enterprise (c) level.

H1: International activities have an effect on company performance at micro enterprise (a), small enterprise (b), and medium enterprise (c) level.

\section{Results}

With regard to the categorization of accounting units which follows the transposition of the Directive of the European Parliament and Council 2013/34/EC (the Directive) into the Czech accounting legislation, the accounting units in the category of micro business units were represented among the interviewed respondents most often. Implementing this Directive, the national accounting has got closer to the IFRS system. Learn more about the IFRS influence e.g. in [24]. Fig. 1 demonstrates the structure of micro, small and medium-sized enterprises according to number of employees in the Czech Republic.

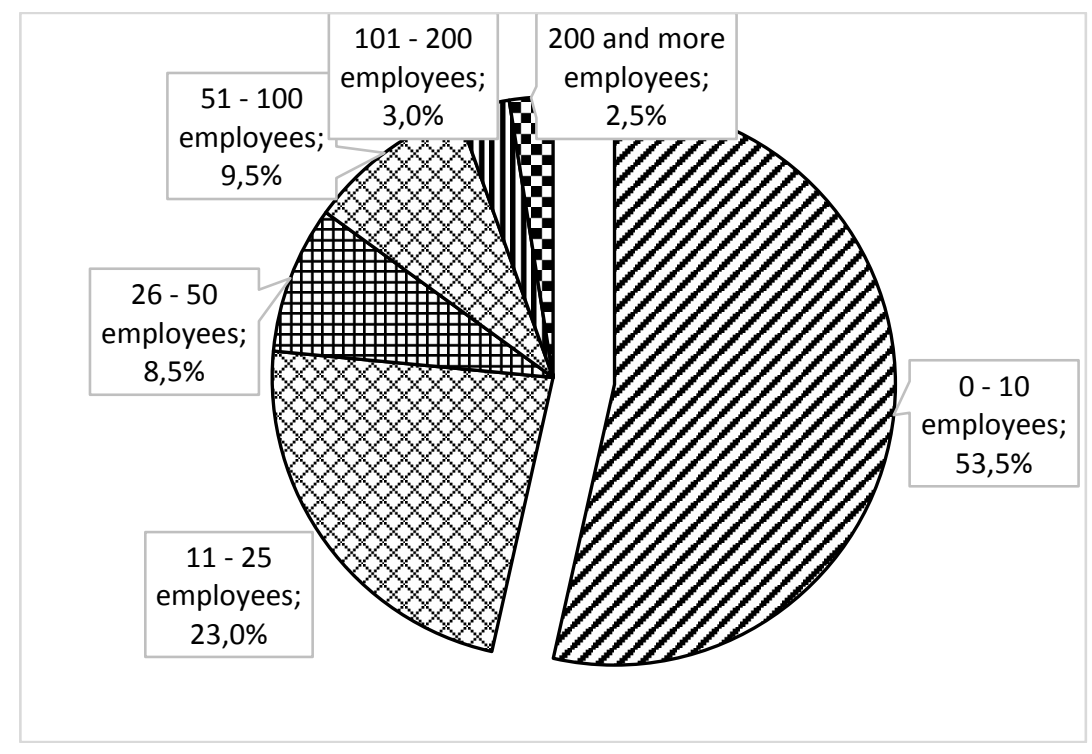

Fig. 1. Categorization of accounting units by the number of employees.

The absolute majority of micro, small and medium-sized enterprises (specifically 400 of the research sample) in the Czech Republic belongs to the first group - they have 0-10 employees and 53.5\% share so they rank first. In the Czech Republic, there operate many small traders who usually cannot afford to employ more people. At the same time, building a business with more employees is very often associated with high initial expenses for which the starting entrepreneurs usually do not have enough financial resources. The second largest representation are businesses with 11-25 employees and 23\% share. On the contrary, the smallest ratio of the total number of examined entities are businesses with 200 or more employees which reach $2.5 \%$. It can be stated that, according to the number of employees, the micro and small businesses with fewer than 25 employees rather prevail and they participate in the total number of businesses with more than three-quarters. It can be therefore said that the influence of these businesses in the Czech Republic is considerable. 
Micro and small enterprises are the least active in the international environment as was found out on the basis of own research of business entities in 2016 and by selected factors: business entity categorization by the number of employees and the length of operation in the domestic and international markets. The representation according to age is the largest in international markets by the medium-sized enterprises, which is confirmed in the Fig. 2.

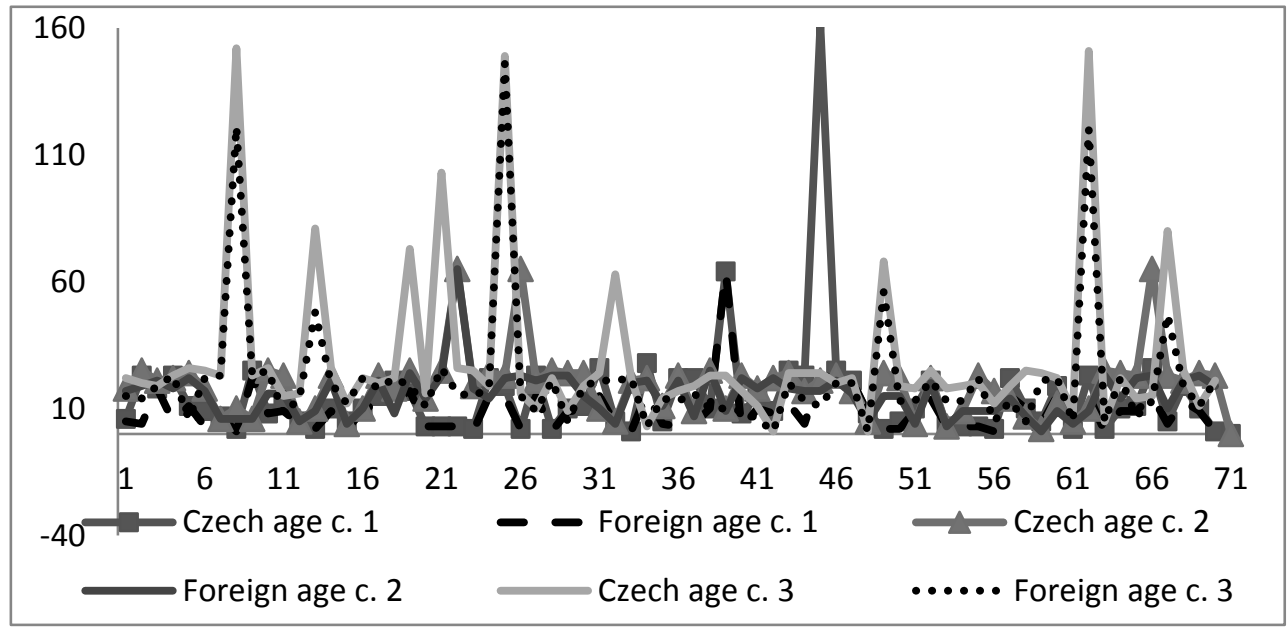

Fig. 2. The length of SMEs operating in the domestic and international environment.

In order to enter international markets, business entities operating in the Czech Republic have the following characteristic features: high industry specialization, lack of financial resources, narrow environment and above all an impact of the free movement of goods and capital, development of modern communication technologies, transport and logistics systems, and other factors that form a stimulus for the development of international business. We include language barriers, knowledge of the market including regulations and legislation, the lack of information about the environment, etc. among the reasons for the low level of activity in the international environment. Operation in international markets has a positive significance for micro, small and medium-sized enterprises.

\subsection{Enterprises operating in the Czech Republic}

Diagnostics of collinearity through correlation, Table 1, was carried out before the analysis of SME's in the international environment. The selected indicators, the dependence of which was tested, include the categorization of accounting units and profitability. All the mentioned items can be found in balance sheet and profit and loss statement. We can be count (profitability) it that is why their interdependence is analyzed. The item total profit or loss was included in profitability indicators because as the subject often shows profit but has no funds and need capital for own business. 
Table 1. Correlation analysis of SMEs.

\begin{tabular}{|c|c|c|c|c|c|c|c|c|c|}
\hline \multicolumn{4}{|c|}{ Micro enterprises } & \multicolumn{3}{c|}{ Small enterprises } & \multicolumn{3}{c|}{ Medium enterprises } \\
\hline & ROE & ROA & ROS & ROE & ROA & ROS & ROE & ROA & ROS \\
\hline ROE & 1.00 & & & 1.00 & & & 1.00 & & \\
\hline ROA & 0.47 & 1.00 & & 0.30 & 1.00 & & 0.76 & 1.00 & \\
\hline ROS & 0.42 & 0.29 & 1.00 & 0.57 & 0.35 & 1.00 & 0.72 & 0.83 & 1.00 \\
\hline
\end{tabular}

As shown in Table 1, the relationships between individual variables show a mostly moderate dependency for micro and small enterprises. The ROA indicator confirms the effectiveness of using the asset structure of the business. Micro and small-sized enterprises show a mostly moderate dependency on foreign capital. Medium-sized enterprises are able to receive and repay foreign resources, which confirms the moderately strong positive dependency of indicators. Enterprises with a long-term existence must be profitable and strive for a financial structure with minimal cost. Table 1 confirmed growing profitability indicators of SMEs.

\subsection{Enterprises operating in the international environment}

Table 2 shows the dependency between individual variables for micro, small and medium enterprises in the international environment. Individual variables such as profitability indicators such as foreign profit and sales.

Table 2. Correlation analysis of SMEs in the international environment.

\begin{tabular}{|c|c|c|c|c|c|c|c|c|c|}
\hline \multicolumn{4}{|c|}{ Micro enterprises } & \multicolumn{3}{c|}{ Small enterprises } & \multicolumn{3}{|c|}{ Medium enterprises } \\
\hline & ROE & ROA & ROS & ROE & ROA & ROS & ROE & ROA & ROS \\
\hline ROE & 1.00 & & & 1.00 & & & 1.00 & & \\
\hline ROA & 0.02 & 1.00 & & 0.10 & 1.00 & & 0.88 & 1.00 & \\
\hline ROS & 0.03 & 0.00 & 1.00 & 0.29 & 0.25 & 1.00 & 0.92 & 0.77 & 1.00 \\
\hline
\end{tabular}

As shown in Table 2, the relationships between individual variables show do no a dependency for micro enterprises. Small enterprises show a mostly moderate dependency and low of foreign capital. Medium enterprises are able to receive and repay foreign capital which confirms the moderately strong positive dependency of indicators. One of the reasons is the long-term company operation in the international environment. Strong dependency of ROA, ROE, and ROC indicators points to positive capital appreciation which is one of the most important indicators of the financial performance of the company. Businesses appropriately manage the entrusted financial resources. As hardly any business can manage without foreign capital these days [24], a typical expense is for example, the loan interest. All the monitored indicators are important documents for the evaluation of business and the international environment. Subsequent analyses were conducted to further analyse these relationships and confirm the hypotheses. Companies must not be only reasonably profitable, but they must be able to reconcile their needs, i.e. bind capital in short-term parts of assets that must be paid by costs associated with their funding and also must seek financial structure with minimal costs of capital, both their own and foreign capital. Compliance with the use of foreign capital for financing the asset part should always correspond to the degree of a company's liquidity and financing rules that significantly affect profitability. 
Table 3 confirms the statistically significant indicator of international activities for medium enterprises.

Table 3. Regression statistics and ANOVA for medium enterprises.

\begin{tabular}{|c|c|}
\hline \multicolumn{2}{|c|}{ Regression statistics } \\
\hline Multiple R & 0.892192 \\
\hline R-squared value & 0.796007 \\
\hline $\begin{array}{c}\text { Set R-squared } \\
\text { value }\end{array}$ & 0.785628 \\
\hline Aver. value error & 20.358406 \\
\hline Observation & 75 \\
\hline
\end{tabular}

\begin{tabular}{|c|c|c|c|c|c|}
\hline \multicolumn{7}{|c|}{ ANOVA } \\
\hline & Difference & SS & MS & F & $\begin{array}{c}\text { Significance } \\
\text { F }\end{array}$ \\
\hline Regression & 2 & 187606.095984 & 93803.047992 & 2.263234 & 1.663234 \\
\hline Residues & 72 & 48077.904016 & 414.464690 & & \\
\hline Total & 75 & 235684.000000 & & & \\
\hline
\end{tabular}

Table 3 confirms the statistically significant indicator of international activities for medium enterprises. H0 is rejected and the selected indicators affect the development of international business. For enterprises, it is important to operate in international markets, which makes them able to achieve higher performance compared to the local environment. Sales, profit or loss, own and foreign capital and for example inventories, demand, prices and competition etc., these affect the outputs of the company in the international environment.

Table 4 confirms no the statistically significant indicator of international activities for micro enterprises. H1 is rejected and selected indicators do not affect the development of international activities.

Table 4. Regression statistics and ANOVA for micro enterprises.

\begin{tabular}{|c|c|}
\hline \multicolumn{2}{|c|}{ Regression statistics } \\
\hline Multiple R & 0.662212 \\
\hline R-squared value & 0.438525 \\
\hline Set R-squared value & 0.378469 \\
\hline Aver. value error & 0.711808 \\
\hline Observation & 321 \\
\hline
\end{tabular}

\begin{tabular}{|c|c|c|c|c|c|}
\hline \multicolumn{7}{|c|}{ ANOVA } \\
\hline & Difference & SS & MS & F & $\begin{array}{c}\text { Significance } \\
\text { F }\end{array}$ \\
\hline Regression & 2 & 10.288777 & 5.144389 & 5.918733 & 10.153312 \\
\hline Residues & 318 & 13.173445 & 0.506671 & & \\
\hline Total & 321 & 23.462222 & & & \\
\hline
\end{tabular}

Table 5 confirms no the statistically significant indicator of international activities for small enterprises. H1 is rejected and selected indicators do not affect the development of international activities. 
Table 5. Regression statistics and ANOVA for small enterprises.

\begin{tabular}{|c|c|}
\hline \multicolumn{2}{|c|}{ Regression statistics } \\
\hline Multiple R & 0.553746 \\
\hline R-squared value & 0.306634 \\
\hline Set R-squared value & 0.260868 \\
\hline Aver. value error & 1.117797 \\
\hline Observation & 189 \\
\hline
\end{tabular}

\begin{tabular}{|c|c|c|c|c|c|}
\hline \multicolumn{7}{|c|}{ ANOVA } \\
\hline & Difference & SS & MS & F & $\begin{array}{c}\text { Significance } \\
\text { F }\end{array}$ \\
\hline Regression & 2 & 20.444936 & 10.222468 & 1.178 & 3.181444 \\
\hline Residues & 186 & 46.230383 & 1.249470 & & \\
\hline Total & 189 & 66.675319 & & & \\
\hline
\end{tabular}

As shown in Table 4, the relationships between individual variables show do no a dependency for micro enterprises. Small enterprises show a mostly moderate dependency and low used of foreign capital (Table 5). Medium -sized enterprises are able to receive and repay foreign resources, which confirms the moderately strong positive dependency of indicators (Table 3). Businesses appropriately manage the entrusted financial resources. As hardly any business can manage without foreign capital these days, the typical expense is for example the loan interest. All monitored indicators are important documents for the evaluation of business and the international environment.

The author concluded that the long-term company operation in the international environment and the international activities are important for balanced financial structure in all enterprises in the Czech Republic. Enterprises must not be only reasonably profitable, but they must be able to reconcile their needs, i.e. bind capital in short-term parts of assets that must be paid by costs associated with their funding and also must seek financial structure with minimal costs of capital, both their own and foreign capital. The low level of financing by the long-term resources by micro and small enterprises and subsequent high interfirm indebtedness of companies or only using owner capital regarding as serious problems of companies. Compliance with the use of foreign capital for financing the asset part should always correspond to the degree of the company's liquidity and financing rules that significantly affect profitability. Other influences that affect the asset and capital structure are: the cost of capital, inventories, accounts receivable, interest, taxes, liquidity, dividend policy, risk, etc., these are absent from this paper.

\section{Discussion and conclusion}

The aim of the article was to analyze selected financial aspects of micro, small and medium enterprises in the Czech Republic in the context of international activities. Evaluation of companies operating in the Czech environment showed that higher growth of microenterprises without international activities. Companies operating in an international environment have shown stronger growth in medium-sized businesses. This is due to the benefits of international cooperation, the size and development of the company, and the growing influence of the international environment on business entities. Unresolved issues persist in the field of accounting harmonization in Europe and related laws, which have a significant impact on financial accounting and are reported by all enterprises. These are not included in this document. 
Research has found that indicators as ROA, ROE and ROC (contain the development of revenue from sales, profits or losses, own and foreign capital and its forms) are important indicators of the assessment of the company's situation. Using these and other indicators, control controls and then evaluates the activity that creates the image of independent business management. However, the indicators examined are not a measure of company success because they do not reflect business risk: the risks of using foreign capital and the related liquidity of the company and the potential threat of insolvency. They only rate the past and take no account of future benefits. Especially growing profitability Indicators, the growing sales and profits of the business entity tell us about the healthy functioning of the company operating on the international market. It is difficult to compare the performance of companies in a highly competitive and international environment. The competition is located in different countries, operating under different conditions and with different legal regulations.

Hence the author concludes, that internalization activities are important for all businesses. It has an influence on their financial structure and on profitability. Therefore the author believes that international activities have a positive impact on SMEs in the Czech Republic mostly in the area of labour employment and growing the size of companies.

\section{References}

1. L. Meixnerová, Š. Zapletalová, Z. Stefanovová, International Business: Selected strategic, managerial and finance aspects [Mezinárodni podnikání: vybrané strategické, manažerské a finančni aspekty]. $1^{\text {st }}$ ed. Prague: C. H. Beck, 203 p. (2017)

2. C. Nicolau, Are SMEs still profitable in an economic crisis? Qualitative research on Romanian entrepreneurship and crisis management. Bulletin of the Transilvania University of Brasov, 8(2), (2015)

3. H. Karadag, Financial Management Challenges In Small and Medium-Sized Enterprises: A Strategic Management Approach. EMAJ: Emerging Markets Journal, 5(1), (2015)

4. A. Dixit, P. Kumar, SMEs and Economic Growth in India: Cointegration Analysis. IUP Journal of Financial Economic. 9(2), (2011)

5. R. Nanu, C.M. Spulbar, R. Buziernescu, Considerations regarding growing financing capacity of SME's. Annals of The University of Oradea, Economic Science Series, 17(3), (2008)

6. E. Di Maria, R., SMEs' growth in international markets: export intensity, export diversification and distribution strategies. Economia e Politica Industriale, 44(3), (2017)

7. P. Newbold, W. L. Carlson, B. M. Thorne, Statistics for Business and Economics. Harlow: Pearson, (2013)

8. A. Majocchi, A. Zucchella, Internationalization and performance findings from a set of Italian SMEs. International Small Business Journal, 21(3), (2003)

9. M. Vochozka, M. Psárska, Factors supporting growth of added value, performance and competitivness of SMEs and selected EU countries. Innovation Management Entrepreneurship and Corporate Sustainability, (2016)

10. Y., P., Hu, I. C. Chang, W. Y. Hsu, Mediating effects of business process for international trade industry on the relationship between information capital and company performance. International Journal of Information Management, 37(5), (2017)

11. H. DeAngelo, R. W. Masulis, Optimal Capital Structure under Corporate and Personal Taxation. Journal of Financial Economics, 8, (1980)

12. M. Brennan, E. Schwartz, E. Corporate Income Taxes, Valuation and the Problem of Optimal Capital Structure. Journal of Business, 51(1), (1978) 
13. J. Lee, Y. S. Hyun, Small and Medium-Sized Japanese Joint Venturtes in Korea. International Small Business Journal. 5(1), (1986).

14. O. Dittmar, Capital Structure in Corporate Spin-Offs. The Journal of Business, 77(1), (2004)

15. A. Strebulaev, Do Test of Capital Structure Theory Mean What They Say. Journal of Finance, 62(4), (2007)

16. L. Strýčková, Factors Determining the Corporate Capital Structure in the Czech Republic from the Perspective of Business Entities. $E+M$, 18(2), (2015)

17. F. Modigliani, M. Miller, M, The Cost of Capital, Corporation Finance and the Theory of Investment. The American Economics Review, 48(3), (1958)

18. R. Aliyev-Ada, D. Hájková, I. Kubicová, The Impact of Monetary Policy on Financing Czech Firms. Czech Journal of Economics and Finance, 65(6), (2015)

19. N. Rodríguez-Masero, Determinants of Capital Structure of Spanish Firms: The Case of Listed Companies in Time of Crisis. Investment Management and Financial Inovation, 13(1), 2016)

20. B. Elliot, J. Elliot, Financial Accounting and Reporting. Harlow: Pearson Education, (2013)

21. P. Santis, A. Albuquerque, F. Lizarelli, Do Sustainable Companies Have a Better Financial Performance? A Study on Brazilian Public Companies. Journal of Cleaner Production, 133, (2016)

22. R. Buglear, Quantitative Methods for Business and Management. Harlow: Pearson, (2012)

23. M. Vochozka, Using neural networks to determine the financial plan. Innovation Management Entrepreneurship and Corporate Sustainability 2016, (2016)

24. J. Hinke, IAS/IFRS and business performance assessment [IAS/IFRS a hodnocení výkonnosti podniku]. Prague: Alfa publishing (2013)

25. S. C. Myers, Determinants of Corporate Borrowing. Journal of Financial Economics, 5(2), (1977) 
